EXTENDED REPORT

\title{
Inhibitory effect of certain neuropeptides on the proliferation of human retinal pigment epithelial cells
}

\author{
J Troger, S Sellemond, G Kieselbach, M Kralinger, E Schmid, B Teuchner, Q A Nguyen, E Schretter- \\ Irschick, W Göttinger
}

See end of article for authors' affiliations

Correspondence to: Josef Troger, MD,

Universitätsk'linik für Augenheilkunde, Anichstrasse 35, A-6020 Innsbruck, Austria; josef.troger@uibk.ac.at

Accepted for publication 23 February 2003
Aims: To define the effect of the neuropeptides substance $P$, calcitonin gene related peptide, vasoactive intestinal polypeptide, neuropeptide $Y$, and secretoneurin on the proliferation of human retinal pigment epithelial (RPE) cells.

Methods: ARPE-19 cells were used. The cells were cultured in Dulbecco's modified Eagle's medium. 1000 and 2000 cells were incubated with the peptides for 3 and 5 days, and the effect of the peptides was evaluated by an ATP lite assay dose dependently. Furthermore, specific antagonists at $10^{-6} \mathrm{M}$ were used to find out whether the effect would be reversed.

Results: In brief, each of the peptides tested had an inhibiting effect. This inhibiting effect was weak but highly significant, averaging $10 \%$ to $15 \%$, and was most pronouncedly seen at concentrations between $10^{-10} \mathrm{M}$ and $10^{-14} \mathrm{M}$. Each antagonist reversed the inhibiting effect fully.

Conclusions: These results clearly indicate that RPE cells are under neural control and the low effective concentration of the peptides may be the one physiologically acting on these cells. The results are of important relevance both physiologically and pathophysiologically: physiologically, the inhibitory effect may mean that these peptides cause the cells to remain in a differentiated condition. Pathophysiologically, the findings are relevant in proliferative vitreoretinopathy where RPE cells proliferate in excess. The authors hypothesise that the inhibiting effect diminishes when these cells are swept out and actively migrate from their physiological location and thus, dedifferentiate and begin to proliferate. This hypothesis improves the knowledge of the initial processes in the pathogenesis of the disease as there seems to be a discrepancy between facilitatory and inhibitory influences favouring the former in proliferative vitreoretinopathy. Furthermore, these neuropeptides constitute the first endogenous inhibitors of RPE cell proliferation.
$\mathrm{R}$ etinal pigment epithelial (RPE) cells constitute highly specialised cells forming a monolayer interposed between the choroid and the neurosensory retina. There is evidence that these cells have several functions in the eye-namely, they transport nutrients from the choroid to the photoreceptors, phagocytose the shed photoreceptor membranes, and ensure firm retinal attachment by net fluid removal from the interphotoreceptor subretinal space.

Neuropeptides are a group of neurotransmitters and/or neuromodulators widely distributed in the central and peripheral nervous system. There are several families of these peptides, the most important and best characterised peptides in the eye are substance $\mathrm{P}$ (SP), calcitonin gene related peptide (CGRP), vasoactive intestinal polypeptide (VIP), and neuropeptide Y (NPY). SP and CGRP are sensory peptides, whereas VIP-ergic nerves are part of the parasympathetic and NPY-ergic nerves part of the sympathetic nervous system (for review, see Stone et $\left.a l^{1}\right)$. SP, CGRP, VIP, and NPY are neuropeptides which innervate the anterior segment of the eye and there are abundant nerve fibres in the choroid predominantly around blood vessels and in the stroma. ${ }^{1}$ Except for CGRP (own observation), these peptides are also present in the retina in various species including humans. In brief, neuropeptides are classic amacrine cell transmitters. ${ }^{1}$ Amacrine cells are a group of cells located in the innermost part of the inner nuclear layer and constitute interneurons with dendrites ramifying into the inner plexiform layer. Furthermore, these peptides occur in displaced amacrine cells in the ganglion cell layer and SP at least is also present in ganglion cells in certain animal species. ${ }^{2-4}$

But there are certain neuropeptides which have not been investigated until now. One of these peptides is secretoneurin
(SN). SN is a peptide first found in $1993^{5}$ and constitutes a cleavage product of secretogranin II. Secretogranin II is a member of the chromogranin family comprising chromogranin A, chromogranin B, secretogranin II, and NESP55. . $^{69}$ These families are the acidic proteins of secretory granules and are also widely distributed within neuroendocrine tissues. $^{6-9}$ In the eye, SN has been found in the human retina in amacrine cells ${ }^{10}$ but in the anterior segment of the eye this peptide has not been explored.

Each of these peptides can influence RPE cells as they can diffuse from both sides to the RPE-from the choroid and from the retina. This study aimed to investigate whether certain neuropeptides influence the proliferation of these cells. This is very important because RPE cells proliferate in definite circumstances. The best example is proliferative vitreoretinopathy (PVR), a disease process, which is characterised by intense proliferation of RPE cells.

\section{MATERIALS AND METHODS}

Cell culture

The experiments were performed with a human RPE cell line, ARPE-19 cells, which were obtained from the American Type Culture Collection (ATTC, PO Box 1549, Manassas, VA 20801, USA). The cells were transferred into $25 \mathrm{~cm}^{2}$ culture flasks and cultured in Dulbecco's modified Eagle's medium (DMEM) containing $200 \mathrm{mM}$ L-glutamine, $0.1 \mathrm{mg} / \mathrm{ml} \mathrm{strep-}$ tomycin, $100 \mathrm{U} / \mathrm{ml}$ penicillin, and $10 \%$ fetal calf serum until a confluence of $80 \%$ was reached. The cells were routinely passaged by dissociation in $0.05 \%$ trypsin and $0.02 \%$ ethylenediaminetetra-acetic acid followed by replating at a split ratio ranging from $1: 3$ to $1: 6$. Cells from passages 3-10 were used for the experiments. For this purpose, the medium 
was removed from the culture flasks and $0.05 \%$ trypsin was added. The cells then were incubated for 5 minutes followed by scraping off the cells. After centrifugation at $1000 \mathrm{rpm}$ for 10 minutes, the cell pellet was resuspended in DMEM medium.

\section{ATP lite assay}

Evaluation of the effect of neuropeptides on cell proliferation was performed with the ATP lite assay, a method standardly used as a measure of cell proliferation. ${ }^{11}{ }^{12}$ ATP is a marker for cell viability because it is present in all metabolically active cells and the concentration declines very rapidly when the cells undergo necrosis or apoptosis. The ATP lite-M assay system is based on the production of light caused by the reaction of ATP with added luciferase and D-luciferin. This is illustrated in the following reaction scheme: ATP + Dluciferin $+\mathrm{O}_{2} \rightarrow$ luciferase, $\mathrm{Mg}^{2+} \rightarrow$ oxyluciferin $+\mathrm{AMP}+\mathrm{PPi}$ $+\mathrm{CO}_{2}+$ light. The emitted light is proportional to the ATP concentration within certain limits.

At the beginning of the proliferation assay, cells were estimated in a "Bürker Zählkammer" (cell counter) and 1000 and 2000 cells in $100 \mu \mathrm{l}$ cell suspension were transferred into a 96 well microtitre plate. After 1 day SP, CGRP, VIP, NPY, and SN were added to the wells. The peptides were purchased from Peninsula Laboratories (Peninsula Laboratories, 601 Taylor Way, San Carlos, CA 94070, USA). The concentrations used were $10^{-6} \mathrm{M}, 10^{-8} \mathrm{M}, 10^{-10} \mathrm{M}, 10^{-12} \mathrm{M}, 10^{-14} \mathrm{M}$, and $10^{-16} \mathrm{M}$. Incubation of cells without addition of neuropeptides served as controls.

Following incubation of the cells for 3 and 5 days at $37^{\circ} \mathrm{C}$ and $5 \% \mathrm{CO}_{2}$, the ATP lite assay was performed (obtained from Packard Bioscience BV, Rigaweg 22, $9723 \mathrm{TH}$, Groningen, Netherlands). For this purpose, $50 \mu \mathrm{l}$ of mammalian cell lysis solution was added to $100 \mu \mathrm{l}$ of cell suspension per well of a microtitre plate and the plate was shaken for 5 minutes in an orbital shaker at $700 \mathrm{rpm}$. This lyses the cells and stabilises the ATP. Then $50 \mu \mathrm{l}$ substrate solution were added to the wells and the microplate was shaken for 5 minutes in an orbital shaker at $700 \mathrm{rpm}$. The plate was placed in the dark for 10 minutes and the luminescence was measured in a microplate scintillation counter (Top count, Packard). The experiments were repeated three times so that 7-16 values were obtained for each concentration and each peptide. Furthermore, experiments with highly specific antagonists were performed-namely, Spantide I, CGRP 8-37, VIP antagonist, and BIPB3226NPY. For this purpose, an effective concentration of the peptides $\left(10^{-14} \mathrm{M}\right)$ was incubated with an excess of the antagonists $\left(10^{-6} \mathrm{M}\right)$. This high concentration was given to certainly saturate receptors. The antagonists were also purchased from Peninsula Laboratories. For SN, an antagonist is not commercially available at present.

\section{Evaluation of the data}

The values obtained by counting on the scintillation counter were processed as percentages: the control values were given as $100 \%$ and the data of peptide effects as percentages of controls. Statistical calculation of differences between controls and peptide effects was performed with the MannWhitney U test $\left({ }^{* * *} \mathrm{p}<0.001\right.$; ${ }^{* *} \mathrm{p}<0.01$; ${ }^{*} \mathrm{p}<0.05$ ).

\section{RESULTS}

The results are illustrated in Figures 1 and 2, where the mean values (SEM) are given as percentages.

\section{Effect of SP}

SP incubated for 3 days exerted an inhibiting effect on both 1000 and 2000 cells. The effect was seen more pronouncedly with 1000 cells with a maximum at $10^{-12} \mathrm{M}(86.7 \%$ (SEM
$2.5 \%)$ of controls; ***), whereas with 2000 cells an $8 \%$ inhibition was reached at this concentration (92.2\% $(1.8 \%) ; * *)$.

Experiments for 5 days also had an inhibiting effect which was less pronounced than that for 3 days, but the effect was significant with 1000 cells at $10^{-10} \mathrm{M}(91.7 \%$ (2.7) of controls; *) and $10^{-12} \mathrm{M}\left(90.3(3.4){ }^{*}\right)$ and with 2000 cells at $10^{-10} \mathrm{M}\left(90.2 \%\right.$ (3.6) of controls; *), $10^{-12} \mathrm{M}(92.0 \%$ (2.4) of controls; *) and $10^{-14} \mathrm{M}(92.8 \%$ (3.4) of controls; *).

Spantide reversed the inhibitory effect fully.

\section{Effect of CGRP}

CGRP, on the other hand, had a modest decreasing effect 3 days after peptide addition. Significance was only reached at $10^{-14} \mathrm{M}$ with 1000 cells $(89.9 \%$ of controls (3.4); *), with 2000 cells at $10^{-10} \mathrm{M}(93.6 \%$ (3.5) of controls; *), and at $10^{-12} \mathrm{M}(91.5 \%(3.1) ; *)$.

Five days of culture with the peptide had a more pronounced effect with 1000 cells. Significance was reached at $10^{-6} \mathrm{M}\left(91.1 \%\right.$ (3.2) of controls; *), at $10^{-8} \mathrm{M}(92.8 \%$ $(2.3) ; *)$, at $10^{-10} \mathrm{M}\left(82.9 \%(2.9) ;{ }^{* * *}\right)$, at $10^{-12} \mathrm{M}(73.3 \%$ (3.6); ***), and at $10^{-14} \mathrm{M}(81.1 \%(2.7) ; * * *)$, whereas incubation of 2000 cells with the peptide failed to be statistically significant.

CGRP 8-37 abolished the decreasing effect.

\section{Effect of VIP}

VIP had the highest significant effect when 2000 cells were incubated for 5 days with the peptide. There was significance at $10^{-6} \mathrm{M}\left(92.3 \%\right.$ of controls (1.9); **), at $10^{-8} \mathrm{M}(90.2 \%$ $(2.3) ; * *)$, at $10^{-10} \mathrm{M}(82.3 \%(3.8) ; * * *)$, at $10^{-12} \mathrm{M}(90 \%$ (1.4);***), and at $10^{-14} \mathrm{M}\left(88.9 \%\right.$ of controls (1.8); $\left.{ }^{* * *}\right)$. The peptides with 1000 cells in culture had a decreasing effect at $10^{-10} \mathrm{M}\left(84.0 \%\right.$ of controls $\left.(4.1) ;{ }^{* *}\right)$, at $10^{-12} \mathrm{M}(90.7 \%$ $(1.8) ; * *)$, and at $10^{-14} \mathrm{M}(87 \%(1.8) ; * * *)$.

Incubating 1000 cells with the peptide for 3 days had a weaker effect $\left(91.0 \%(3.4)\right.$ of controls at $10^{-12} \mathrm{M}$; * and $89.3 \%$ (3.3) at $10^{-14} \mathrm{M}$; *). But 2000 cells in culture for 3 days with the peptide revealed significance at $10^{-8} \mathrm{M}(87 \%$ (3.5) of controls; **), at $10^{-10} \mathrm{M}\left(89.7 \%(3.4) ;{ }^{* *}\right)$, at $10^{-12} \mathrm{M}$ $\left(87 \%(3.4) ;{ }^{* *}\right)$ and at $10^{-14} \mathrm{M}(86.7 \%(3.2) ; * *)$.

Again the antagonist reversed the inhibition.

\section{Effect of NPY}

NPY had a decreasing effect on cell proliferation following 3 days in culture both for $1000(90.6 \%$ of controls (2.7) at $10^{-8} \mathrm{M} ;{ }^{* *} ; 89.3 \%(2.8)$ at $10^{-10} \mathrm{M} ; * * ; 89.3 \%(2.8)$ at $10^{-12} \mathrm{M} ;{ }^{* *}$ and $86.2 \%(4.0)$ at $\left.10^{-14} \mathrm{M} ;{ }^{* * *}\right)$ and 2000 cells (88.3\% of controls (1.9) at $10^{-8} \mathrm{M}$; ${ }^{* * *} ; 86.1 \%$ of controls (2.7) at $10^{-10} \mathrm{M}$; ***; $85.2 \%$ of controls (2.8) at $10^{-12} \mathrm{M}$; *** and $84.4 \%(3.5)$ at $\left.10^{-14} \mathrm{M} ; * * *\right)$.

Culturing 1000 cells with NPY for 5 days had an inhibiting effect at $10^{-6} \mathrm{M}(90.9 \%$ of controls $(2.4) ; * *)$, at $10^{-8} \mathrm{M}$ (91.7\% of controls (1.8); $\left.{ }^{* *}\right)$, at $10^{-10} \mathrm{M}\left(89.8 \%(2.2) ;{ }^{* * *}\right)$, at $10^{-12} \mathrm{M}(80.2 \%(3.4) ; * * *)$, and at $10^{-14} \mathrm{M}(85.5 \%$ of controls $\left.(1.8) ; *^{* *}\right)$. Significance was also reached when 2000 cells were incubated with the peptide for 5 days at $10^{-6} \mathrm{M}\left(88.9 \%\right.$ of controls (2.4); $\left.{ }^{* *}\right)$. at $10^{-8} \mathrm{M}(91.9 \%$ (2.7); $\left.{ }^{*}\right)$, at $10^{-10} \mathrm{M}\left(86.7 \%(2.4) ;{ }^{* * *}\right)$, at $10^{-12} \mathrm{M}(87.5 \%(2.7)$; $\left.{ }^{* * *}\right)$ and at $10^{-14} \mathrm{M}\left(91.5 \%(2.3)\right.$ of controls; $\left.{ }^{* *}\right)$.

The antagonist fully reversed the inhibiting effect.

\section{Effect of SN}

Another peptide, SN, also decreased cell proliferation. Incubating 1000 cells and 2000 cells for 3 days respectively, revealed a significant inhibiting effect at $10^{-6} \mathrm{M}(88.4 \%$ (2.2) of controls; ***), at $10^{-8} \mathrm{M}\left(93.3 \%(2.4) ;{ }^{* *}\right)$, at $10^{-12} \mathrm{M}$ $(86.6 \%(2.4) ; * * *)$, and $10^{-14} \mathrm{M}\left(91.6 \%(2.4) ;{ }^{* *}\right)$. Cultures with 2000 cells had an inhibiting effect, which was 

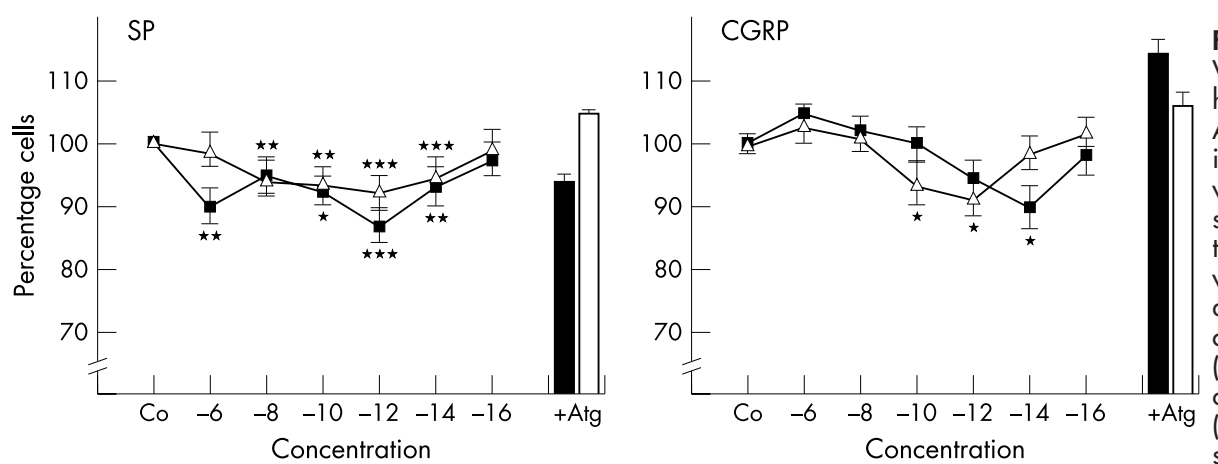

Figure 1 Effect of SP, CGRP, NPY VIP, and SN on the proliferation of

human RPE cells incubated for 3 days. ARPE-19 cells were cultured standardly in DMEM medium and experiments were performed with 1000 cells (solid squares) and 2000 cells (open triangles). The concentrations used were between $10^{-6} \mathrm{M}$ and $10^{-16} \mathrm{M}$ and incubation of cells without addition of neuropeptides served as controls (Co). Furthermore, an effective concentration of each peptide

$\left(10^{-14} \mathrm{M}\right)$ was incubated with a highly specific antagonist at a concentration of
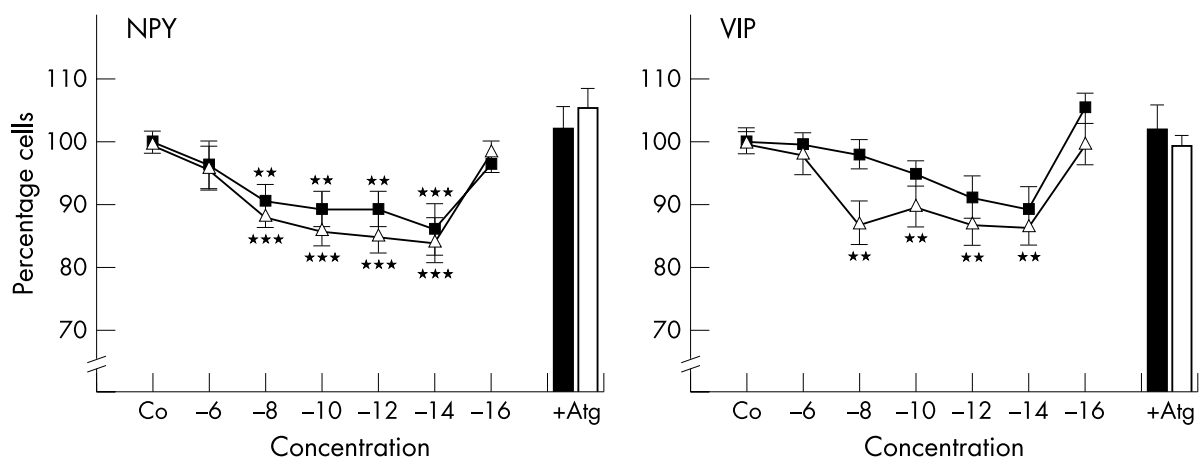
$10^{-6} \mathrm{M}$ (+Atg). 1000 cells incubated with the peptides and the antagonists represent solid bars, 2000 cells open bars. Controls $(n=15-24)$, peptide effects $(n=7-16)$, and antagonist effects $(n=5-8)$ were evaluated by an ATP lite assay. The values obtained by counting on a scintillation counter were processed as percentages: the control values were given as $100 \%$ and the data of peptide effects as percentages of controls. Mean values (SEM) are given. Statistical calculation of differences between controls and peptide effects was performed with the Mann-Whitney $U$ test ( $^{* * *} p<0.001$;

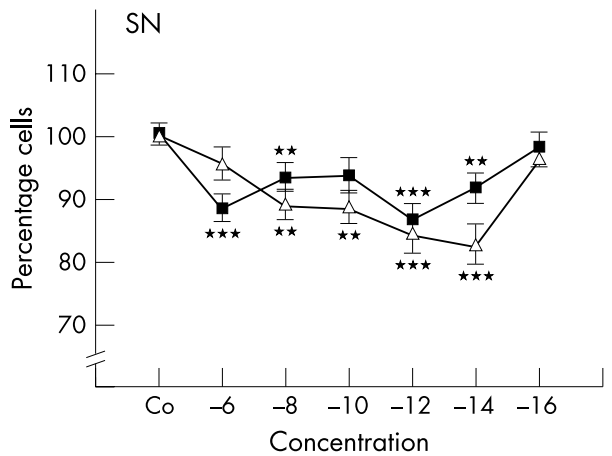
${ }^{* *} p<0.01,{ }^{*} p<0.05$ )

significant at $10^{-8} \mathrm{M}\left(89.2 \%(2.5)\right.$ of controls; $\left.{ }^{* *}\right), 10^{-10} \mathrm{M}$ $\left(88.6 \%(2.6) ;{ }^{* *}\right), 10^{-12} \mathrm{M}\left(84.4 \%(3.1) ;{ }^{* *}\right)$ and $10^{-14} \mathrm{M}$ $(82.8 \%(3.3) ; * * *)$.

Results obtained with 1000 and 2000 cells for 5 days in culture also had an inhibitory effect which was very similar. For 1000 cells, significance was reached at $10^{-8} \mathrm{M}(93.4 \%$ (3.3) of controls; *), at $10^{-10} \mathrm{M}(93.1 \%(2.4) ; *)$, at $10^{-12} \mathrm{M}$ (88.4\% (2.3); $\left.{ }^{* * *}\right)$, and $10^{-14} \mathrm{M}\left(90.8 \%(2.5) ;{ }^{* *}\right)$. For 2000 cells, significance was obtained at $10^{-8} \mathrm{M}(92.6 \%$ (3.5) of controls; *), at $10^{-10} \mathrm{M}\left(89.7 \%(2.0) ;{ }^{*}\right), 10^{-12} \mathrm{M}(88.1 \%$ $(2.0) ; * * *)$, and $10^{-14} \mathrm{M}(81.4 \%(4.0) ; * * *)$.

\section{DISCUSSION}

This study aimed to investigate whether certain neuropeptides influence the proliferation of RPE cells. Thus, the authors found a weak but significant inhibiting effect averaging $10 \%$ to $15 \%$. Concerning $\mathrm{SN}$, this is the first biological effect of this peptide in the eye. Surprisingly, each of the peptides studied acted in an inhibitory manner and the effect was seen most pronouncedly between $10^{-10} \mathrm{M}$ and $10^{-14} \mathrm{M}$. This concentration is low but taking into account that there is a distance between the RPE monolayer on the one side and the choroid and the retina on the other side, this concentration may be the one being physiologically effective on these cells. The results tend to be highly specific for two reasons: firstly, the authors incubated both 1000 and 2000 cells with the neuropeptides for 3 and 5 days and the outcome was qualitatively the same. Secondly, the authors used an antagonist to verify whether the effect would be reversed and this was clearly the case. The results are not identical to those of Koh et al who found a stimulating effect of VIP, ${ }^{13}$ or those of Kishi et al who found a stimulating effect of SP, CGRP, and $\beta$ endorphin. ${ }^{14}$ The discrepancy can be explained, firstly, by species differences as the present study used human RPEs and, secondly, methodologically. Koh et al and Kishi et al used ${ }^{3} \mathrm{H}$-thymidine uptake as their method whereas our study preferred an ATP lite assay. Both methods are well established, but the authors chose the latter one, as it constitutes a more modern method and an endogenous parameter in our opinion represents a better indicator for estimation of cell proliferation.

The results are of relevance both physiologically and pathophysiologically. Physiologically, the findings indicate that RPE cells are under neural control: the inhibitory effect of these peptides on the proliferation of RPE cells may mean that those peptides cause the cells to maintain a differentiated condition. Indeed, Koh et al found that VIP promotes the melanogenesis which is in agreement with this hypothesis. $^{13}{ }^{15}$ These peptides may also be among those agents which influence RPE cells to form a monolayer in the ontogenesis and which prevent them proliferating in excess. In the retina, at least SP appears to have a fundamental role in the development of inner retinal circuits. ${ }^{16}$ RPE cells are in close proximity to the retina and therefore certain 

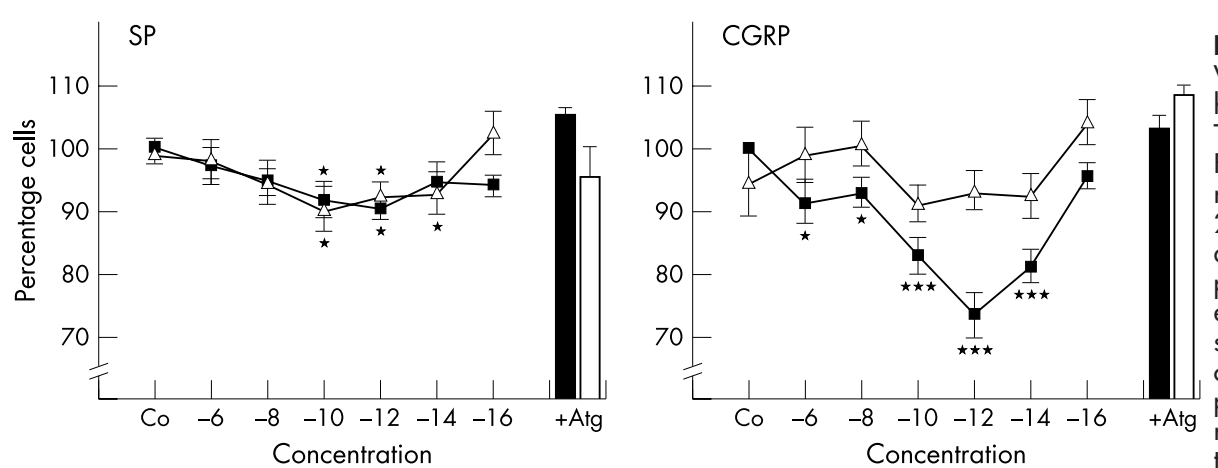

Figure 2 Effect of SP, CGRP, NPY VIP, and SN on the proliferation of human RPE cells incubated for 5 days. The protocol is the same as described in Figure 1. In brief, open triangles represent 1000 cells and solid squares 2000 cells. The effect was evaluated dose dependently (controls: $\mathrm{n}=16-23$; peptide effects: $n=9-15$; antagonist effects: $n=5-10$ ) and highly specific antagonists at a concentration of $10^{-6} \mathrm{M}$ clearly reversed the peptide effects (+Atg). Solid bars represent incubation of 1000 cells with the antagonists, open bars incubation
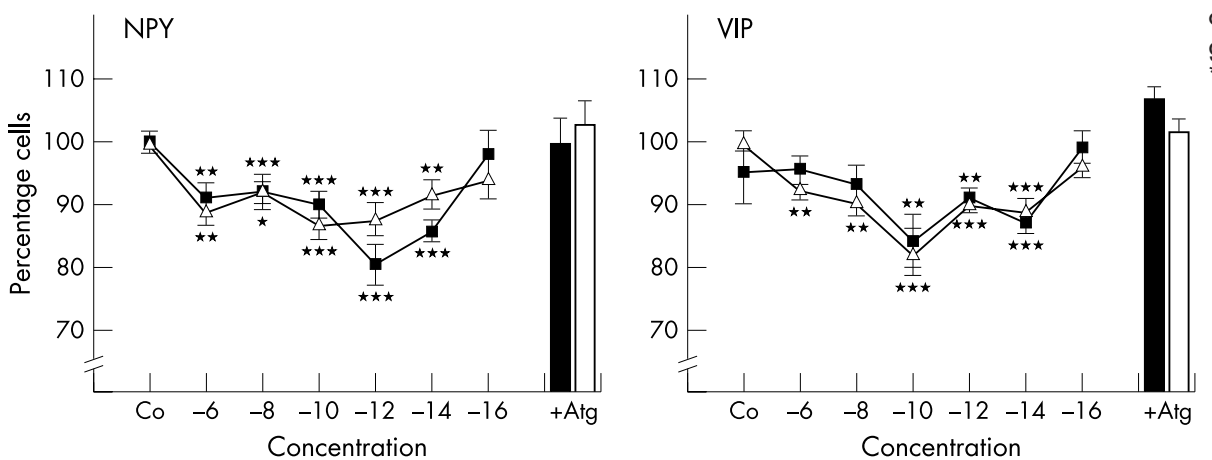
of 2000 cells. Mean values (SEM) are given (*** $p<0.001$, ${ }^{* *} p<0.01$, $p<0.05)$.
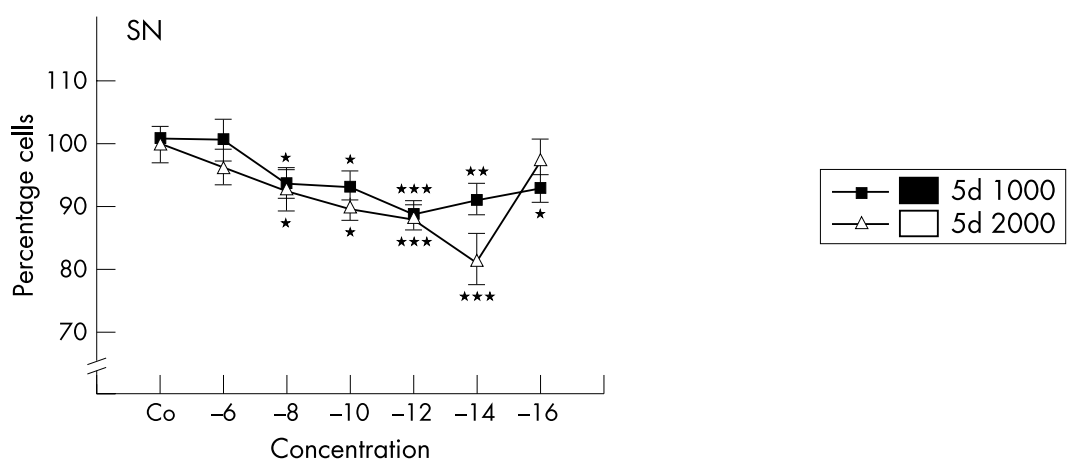

neuropeptides may have an influence on the development of the RPE monolayer too.

The results are also pathophysiologically relevant, as the proliferation of retinal pigment epithelial cells is a hallmark of PVR (reviews, see Machemer, ${ }^{17}$ Hiscott et al, ${ }^{18}$ Wiedemann et $a l,{ }_{19}^{19}$ and Weller et $\left.a l^{20}\right)$. The decisive step in the pathogenesis of PVR is the first phase, in particular the infiltration of mainly RPE cells into the preretinal or subretinal space, or both, where the cells dedifferentiate and proliferate in excess. The exact mechanisms leading to migration and proliferation of RPE cells are still not exactly clear. The inhibiting effect of the neuropeptides found in this study provokes the authors to define the following hypothesis: in the physiological state, RPE cells remain in a differentiated condition where at least certain neuropeptides act in an inhibitory way on cell proliferation. In PVR, where these cells are swept out and actively migrate from their physiological location to the preretinal or subretinal space, this inhibitory effect of the retina and the choroid diminishes. Thus, RPE cells first dedifferentiate and become myofibroblasts and then they begin to proliferate. It must be emphasised that the absence of the inhibiting effect of neuropeptides may not be the main reason for the development of PVR because there are several growth factors and cytokines responsible for evolution of the disease which act in a migratory way and/or have a proliferative potency. This knowledge is based on the finding that certain mediators are present in the vitreous and subretinal fluids of patients with PVR, in particular PDGF, ${ }^{21}{ }^{22} \mathrm{HGF}^{23}$ IL-1, IL-6, $\gamma$-IFN, ${ }^{24-26}$ IL-8, MCP-1, M$\mathrm{CSF}^{27}{ }^{28}$ or TNF- $\alpha^{29}$ and distinct factors have been detected in epiretinal membranes-that is, $\mathrm{EGF}^{30}$ acidic and basic FGF, ${ }^{31}{ }^{32}$ PDGF, ${ }^{33}$ VEGF, and TNF $\alpha{ }^{34}$ TGF- $\beta{ }^{35}$ IL- $1 \beta$ or IL$6 .^{36}$ The relevance of growth factors and cytokines should be emphasised by the fact that experimental PVR can be attenuated by inhibiting the platelet derived growth factor receptor $^{37}$ and that high vitreous levels of IL-6 have been found to be a risk factor for the development of PVR. ${ }^{38}$ Therefore, both the absence of the inhibiting effect of neuropeptides together with an imbalance between adhesive/counteradhesive molecules stimulating RPE cells to dissociate from Bruch's membrane (for review, see Hiscott et $\left.a \mathrm{l}^{39}\right)$, and the formation of an adequate milieu with synthesis of growth factors and cytokines, may be mainly responsible in the pathogenesis of PVR. Thus, this hypothesis provides a better understanding about the initial processes leading to the formation of epiretinal membranes. However, there seems to be at least a discrepancy between facilitatory and inhibitory influences favouring the former in PVR. It must be emphasised that the effect of single neuropeptides is only weak in vitro. But acting together, the effect may become additive even in vivo and then may indeed be relevant both physiologically and pathophysiologically.

The most important problem concerning PVR is the therapeutic management. Currently, the only effective 
therapy is to surgically remove the membranes. Furthermore, most clinicians use systemic cortisone to inhibit cell proliferation although the effect is not always beneficial. Recently, there have been several studies published which aimed to explore whether certain substances have an inhibiting effect on the proliferation of RPE cells in vitro, in particular tranilast, ${ }^{40}$ genistein, ${ }^{41}{ }^{42}$ ciprofloxacin, ${ }^{43}$ vitamin $\mathrm{E}^{44}$ minoxidil, ${ }^{45}$ hypericin, ${ }^{46}$ cis-hydroxyproline, ${ }^{47}$ retinoic acid, ${ }^{48} 49$ aclacinomycin $\mathrm{A}^{50}$ daunorubicin, ${ }^{51} \mathrm{~N}, \mathrm{~N}$-dimethyladriamycin, ${ }^{52}$ or cis retinoic acid. ${ }^{53}$ These substances have an inhibiting effect but possible toxic side effects restrict their usefulness as treatment in PVR. The neuropeptides tested in this study are endogenous elements and, therefore, one could recommend employing these peptides as therapeutic targets. Consequently, it would be of interest to investigate whether combinations of certain neuropeptides have an additive effect in vitro as the effect of single peptides is only weak. However, further studies are necessary to evaluate the efficacy of neuropeptides in PVR, in particular to find out whether and which combinations have an additive effect, to find out whether and which neuropeptides act in a migratory way and, if the latter is not the case, to test them finally in PVR animal models by intravitreal application. Nevertheless, it must be emphasised that the neuropeptides in this study constitute the first endogenous inhibitors of RPE cell proliferation. In the literature, to our knowledge, only TGF$\beta$ has been described as a potent endogenous inhibitory substance ${ }^{48}$ but TGF- $\beta$ is known as a fibrogenic cytokine and the concentration in the vitreous of patients with PVR correlates well with the extent of fibrosis. ${ }^{54}$

In conclusion, the authors found a weak, but highly significant inhibitory effect of certain neuropeptides on the proliferation of human RPE cells. The results indicate that the cells are under neural control and these neuropeptides constitute the first endogenous inhibitors of RPE cell proliferation.

\section{ACKNOWLEDGEMENT}

Grants: This study was supported by grants from the Austrian Science Foundation (FWF, P14022-Med to JT).

\section{Authors' affiliations}

J Troger, S Sellemond, G Kieselbach, M Kralinger, E Schmid, B Teuchner, Q A Nguyen, E Schretter-Irschick, W Göttinger, Department of Ophthalmology and Optometry, University Clinic, Anichstrasse 35, 6020 Innsbruck, Austria

\section{REFERENCES}

1 Stone RA, Kuwayama Y, Laties AM. Regulatory peptides in the eye. Experientia 1987;43:781-800.

2 Brecha N, Johnson D, Bolz J, et al. Substance P-immunoreactive retinal ganglion cells and their central axon terminals in the rabbit. Nature 1987:327:155-8.

3 Ehrlich D, Kayser KT, Karten HJ. Distribution of substance P-like immunoreactive retinal ganglion cells and their pattern of termination in the optic tectum of chick (Gallus gallus). J Comp Neurol 1987;266:220-32.

4 Takatsuji K, Miguel-Hidalgo JJ, Tohyama M. Substance P-immunoreactive innervation from the retina to the suprachiasmatic nucleus in the rat. Brain Res 1991;568:223-9

5 Kirchmair R, Hogue-Angeletti R, Gutierrez J, et al. Secretoneurin-a neuropeptide generated in brain, adrenal medulla and other endocrine tissues by proteolytical processing of secretogranin II (chromogranin C). Neuroscience 1993;54:1-4.

6 Fischer-Colbrie R, Hagn C, Schober M. Chromogranins A, B and C: widespread constituents of secretory vesicles. Ann N Y Acad Sci 1987:493:120-34.

7 Winkler H, Fischer-Colbrie R. The chromogranins A and B: the first 25 years and future perspectives. Neuroscience 1992;49:497-528.

8 Winkler H, Fischer-Colbrie R. Regulation of the biosynthesis of large dense core vesicles in chromaffin cells and neurons. Cell Mol Neurobiol 1998; 18:193-209

9 Ischia R, Lovisetti-Scamihorn P, Hogue-Angeletti R, et al. Molecular cloning and characterization of NESP55, a novel chromogranin-like precursor of a peptide with 5-HT1B receptor antagonist activity. J Biol Chem

1997:272:11657-62.
10 Overdick B, Kirchmair R, Marksteiner J, et al. Presence and distribution of a new neuropeptide, secretoneurin, in human retina. Peptides 1996; 17: $1-4$.

11 Kangas L, Grönroos M, Nieminen AL. Bioluminescence of cellular ATP: a new method for evaluating agents in vitro. Med Biol 1984;62:338-43.

12 Crouch SPM, Kozlowski R, Slater KJ, et al. The use of ATP bioluminescence as a measure of cell proliferation and cytotoxicity. J Immunol Methods 1993:10:81-8.

13 Koh SW, Kane GJ. VIP stimulates proliferation and differentiation of the cultured retinal pigment epithelium with disparate potencies. Cell Biol Int Rep 1992; 16:175-83.

14 Kishi H, Mishima HK, Sakamoto I, et al. Stimulation of retinal pigment epithelial cell growth by neuropeptides in vitro. Curr Eye Res 1996; 15:708-13

15 Koh SM. VIP enhances the differentiation of retinal pigment epithelium in culture: from cAMP and pp60c-src to melanogenesis and development of fluid transport capacity. Prog Retin Eye Res 2000;19:669-88.

16 Casini G, Brecha NC, Bosco L, et al. Developmental expression of neurokinin1 and neurokinin-3 receptors in the rat retina. J Comp Neurol 2000:421:275-87.

17 Machemer R. Proliferative vitreoretinopathy (PVR): a personal account of its pathogenesis and treatment. Proctor lecture. Invest Ophthalmol Vis Sci 1988;29:1771-83.

18 Hiscott P, Sheridan C, Magee RM, et al. Matrix and the retinal pigment epithelium in proliferative retinal disease. Prog Ret Eye Res 1999;18:167-90.

19 Wiedemann P, Weller M, Heimann K. Proliferative vitreoretinopathy: new discoveries in pathophysiology and therapy. Klin Monatsbl Augenheilkd 1990:196:121-7.

20 Weller M, Wiedemann P, Heimann K. Proliferative vitreoretinopathy-is it anything more than wound healing at the wrong place? Int Ophthalmol 1990;14:105-17.

21 Cassidy L, Barry P, Shaw C, et al. Platelet derived growth factor basic levels in the vitreous of patients with vitreoretinal disorders. Br J Ophthalmol 1998;82:181-5.

22 Andrews A, Balciunaite E, Leong FL, et al. Platelet-derived growth factor plays a key role in proliferative vitreoretinopathy. Invest Ophthalmol Vis Sci 1999:40:2683-9.

23 Briggs MC, Grierson I, Hiscott P, et al. Active scatter factor (HGF/SF) in proliferative vitreoretinal disease. Invest Ophthalmol Vis $\mathrm{Sci}_{\mathrm{c}}$ 2000:41:3085-94.

24 Limb GA, Little BC, Meager A, et al. Cytokines in proliferative vitreoretinopathy. Eye 1991;5:686-93.

25 Kauffmann DJ, van Meurs JC, Mertens DA, et al. Cytokines in vitreous humor: interleukin-6 is elevated in proliferative vitreoretinopathy. Invest Ophthalmol Vis Sci 1994;35:900-6.

26 El-Ghrably IA, Dua HS, Orr GM, et al. Intravitreal invading cells contribute to vitreal cytokine milieu in proliferative vitreoretinopathy. $\mathrm{Br} J$ Ophthalmol 2001;85:461-70.

27 Elner SG, Elner VM, Jaffe GJ, et al. Cytokines in proliferative diabetic retinopathy and proliferative vitreoretinopathy. Curr Eye Res 1995; 14:1045-53.

28 Aksunger A, Or M, Okur H, et al. Role of interleukin 8 in the pathogenesis of proliferative vitreoretinopathy. Ophthalmologica 1997;211:223-5.

29 El-Ghrably IA, Dua HS, Orr GM, et al. Detection of cytokine mRNA production in infiltrating cells in proliferative vitreoretinopathy using reverse transcription polymerase chain reaction. Br J Ophthalmol 1999;83:1296-9.

30 Heidenkummer HP, Kampik H. Immunohistochemical localization of epidermal growth factor receptor in a human epiretinal membrane. Graefes Arch Clin Exp Ophthalmol 1991;229:492-6.

31 Malecaze F, Mathis A, Arne JL, et al. Localization of acidic fibroblast growth factor in proliferative vitreoretinopathy membranes. Curr Eye Res $1991 ; 10: 719-29$

32 Hueber A, Wiedemann $P$, Esser $P$, et al. Basic fibroblast growth factor mRNA bFGF peptide and FGF receptor in epiretinal membranes of intraocular proliferative disorders (PVR and PDR). Int Ophthalmol 1996-97; 20:345-50.

33 Robbins SG, Mixon RN, Wilson DJ, et al. Platelet-derived growth factor ligands and receptors immunolocalized in proliferative retinal diseases. Invest Ophthalmol Vis Sci 1994:35:3649-63.

34 Armstrong D, Augustin AJ, Spengler R, et al. Detection of vascular endothelial growth factor and tumor necrosis factor alpha in epiretinal membranes of proliferative diabetic retinopathy, proliferative vitreoretinopathy and macular pucker. Ophthalmologica 1998;212:410-14.

35 Bochaton-Piallat ML, Kapetanios AD, Donati G, et al. TGF-betal, TGF-beta receptor II and ED-A fibronectin expression in myofibroblast of vitreoretinopathy. Invest Ophthalmol Vis Sci 2000;41:2336-42

36 Limb GA, Early O, Jones SE, et al. Expression of mRNA coding for TNFalpha, IL- 1 beta and IL- 6 by cells infiltrating retinal membranes. Graefes Arch Clin Exp Ophthalmol 1994;232:646-51.

37 Ikuno Y, Leong FL, Kazlauskas A. Attenuation of experimental proliferative vitreoretinopathy by inhibiting the platelet-derived growth factor receptor. Invest Ophthalmol Vis Sci 2000:41:3107-16.

38 Kon CH, Occleston NL, Aylward GW, et al. Expression of vitreous cytokines in proliferative vitreoretinopathy: a prospective study. Invest Ophthalmol Vis Sci 1999:40:705-12.

39 Hiscott P, Sheridan C, Magee RM, et al. Matrix and the retinal pigment epithelium in proliferative retinal disease. Prog Ret Eye Res 1999;18:167-90.

40 Ito S, Sakamoto T, Tahara Y, et al. The effect of tranilast on experimental proliferative vitreoretinopathy. Graefes Arch Clin Exp Ophthalmol 1999;237:691-6. 
41 Krott R, Lebek J, Grisanti S, et al. Antiproliferative Wirkung von Genistein auf kultivierte retinale Pigmentepithelzellen vom Schwein. Ophthalmologica 2000;214:296-300.

42 Yoon HS, Rho $\mathrm{SH}$, Jeong JH, et al. Genistein produces reduction in growth and induces apoptosis of rat RPE-J cells. Curr Eye Res 2000;20:215-24.

43 Koutsandrea CN, Miceli MV, Peyman GA, et al. Ciprofloxacin and dexamethasone inhibit the proliferation of human retinal pigment epithelial cells in culture. Curr Eye Res 1991;10:249-58.

44 Mojon D, Boscoboinik D, Haas A, et al. Vitamin E inhibits retinal pigment epithelial cell proliferation in vitro. Ophthalmic Res 1994;26: 304-9.

45 Handa JT, Murad S, Jaffe GJ. Inhibition of cultured human RPE cell proliferation and lysyl hydroxylase activity by hydroxy derivatives of minoxidil. Invest Ophthalmol Vis Sci 1994;35:463-9.

46 Harris MS, Sakamoto T, Kimura H, et al. Hypericin inhibits cell growth and induces apoptosis in retinal pigment epithelial cells: possible involvement of protein kinase C. Curr Eye Res 1996;15:255-262.

47 Yoo JS, Sakamoto T, Spee C, et al. cis-hydroxyproline inhibits proliferation, collagen synthesis, attachment, and migration of cultured bovine retinal pigment epithelial cells. Invest Ophthalmol Vis Sci 1997;38:520-8.
48 Kishi $\mathbf{H}$ Mishima HK Yamashita U. Effects of retinoic acid and TGF-beta 1 on the proliferation and melanin synthesis in chick retinal pigment epithelial cells in vitro. Curr Eye Res 1998;17:483-6.

49 Kishi H, Kuroda E, Mishima HK, et al. Role of TGF-beta in the retinoic acidinduced inhibition of proliferation and melanin synthesis in chick retinal pigment epithelial cells in vitro. Cell Biol Int 2001;25:1125-9.

50 Steinhorst UH, Chen EP, Hatchell DL, et al. Aclacinomycin A in the treatmen of experimental proliferative vitreoretinopathy. Efficacy and toxicity in the rabbit eye. Invest Ophthalmol Vis Sci 1993;34:1753-60.

51 Khawley JA, Saloupis $\mathrm{P}$, Hatchell DL, et al. Daunorubicin treatment in a refined experimental model of proliferative vitreoretinopathy. Graefes Arch Clin Exp Ophthalmol 1991;229:464-7.

52 Steinhorst UH, Chen EP, Machemer R, et al. N,N-dimethyladriamycin for treatment of experimental proliferative vitreoretinopathy: efficiacy and toxicity on the rabbit retina. Exp Eye Res 1993;56:489-95.

53 Fekrat S, de Juan E Jr, Campochiaro PA. The effect of oral 13-cis-retinoic acid on retinal redetachment after surgical repair in eyes with proliferative vitreoretinopathy. Ophthalmology 1995;102:412-18.

54 Conner TB Jr, Roberts AB, Sporn MB, et al. Correlation of fibrosis and transforming growth factor-beta 2 levels in the eye. J Clin Invest 1989;83:1661-6.

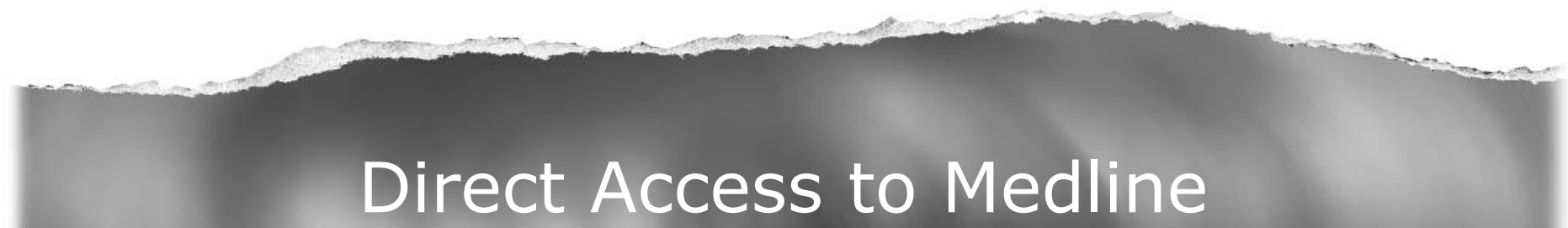

Medline

Link to Medline from the homepage and get straight into the National Library of Medicine's premier bibliographic database. Medline allows you to search across 9 million records of bibliographic citations and author abstracts from approximately 3,900 current biomedical journals.

\section{www.bjophthalmol.com}

